$\begin{array}{ll} & \text { Etnográfica } \\ \text { etnográfica } & \text { Revista do Centro em Rede de Investigação em }\end{array}$

Antropologia

vol. $15(2) \mid 2011$

Vol. $15(2)$

\title{
Ethnography as tradition in Africa
}

João de Pina-Cabral

\section{(Q) OpenEdition \\ Journals}

\section{Electronic version}

URL: https://journals.openedition.org/etnografica/991

DOI: 10.4000/etnografica.991

ISSN: 2182-2891

\section{Publisher}

Centro em Rede de Investigação em Antropologia

\section{Printed version}

Date of publication: 1 June 2011

Number of pages: 379-394

ISSN: 0873-6561

\section{Electronic reference}

João de Pina-Cabral, "Ethnography as tradition in Africa", Etnográfica [Online], vol. 15 (2) | 2011, Online since 23 October 2011, connection on 12 February 2022. URL: http://journals.openedition.org/ etnografica/991; DOI: https://doi.org/10.4000/etnografica.991

\section{(c) (i) (9)}

Etnográfica is licensed under a Creative Commons Attribution-NonCommercial 4.0 International License. 


\section{Ethnography as tradition in Africa}

João de Pina-Cabral ${ }^{1}$

THIS DOSSIER COMPRISES REVIEWS OF FIVE RECENTLY PUBLISHED Africanist ethnographies: some fully contemporary (by Ramon Sarró, Mike McGovern and Harry West); one previously unread (by David Webster); and, finally, a major classic re-edited in Portuguese (Junod's Unicamp edition). Ramon Sarró and I decided to organize it because we felt that we could highlight in this way how the practice of ethnography, old as it is, will remain fully alive tomorrow - no less in English than in the Portuguese-speaking world, which is witnessing a new revival of interest in the anthropology of Africa.

"Ethnography as tradition in Africa" is our way of stressing that our discipline's favoured methodology is an embodied engagement with the human world with roots in forms of curiosity that are very ancient; they emerged long before academic anthropology was constituted in the mid-nineteenth century. Ethnography, thus, is not open to being reinvented at every new juncture, either as a mode of scientific analysis or as a mode of reporting on experience. In this sense, we too stand in the shoulders of giants. Only seen from the perspective of that historical succession can the contemporary ethnographies we collect in this dossier achieve the full plenitude of their meaning.

In the following pages, I draw bridges to the past as a mode of situating the main challenges of the present moment. The brilliance of the contemporary ethnographies that are being published or translated into Portuguese is evidence of the liveliness of this tradition; the contemporary publication and translation of ethnographic treasures of the past is evidence of how our new work relies on echoes of that heritage. 


\section{SCHAPERA RHETORICS}

The following are the starting words to Isaac Schapera's book Rainmaking Rites of Tswana Tribes (1971):

"I started fieldwork among the Kgatla on 14 October 1929. That was the day on which Molefi, then twenty years old, was installed as chief of the tribe. The previous afternoon there had been a violent thunderstorm, and five people were killed by lightning. But the heavy downpour of rain, the first of the new season, was hailed with general delight (so I was told) as 'the best of omens for Molefi's reign'" (1971:2).

Thus he launches his narrative. ${ }^{2}$ He sets himself and the actors in the field and we are left with no doubt that, although we might not yet be attuned to it, the issue is of relevance to the Tswana people; thus, it is of relevance to all of us humans. And he knows what they think; for they told him. But still, he suggests, there is something to learn that is not immediately available. There is an aporia to mediate: how can they rejoice in the face of a thunderstorm that killed five people? His book is about to illuminate all this.

Yet, Schapera does not press it on us; he leaves the aporia understated for the readers to work out, certain that they will be affected by it even as it hardly surfaces in their conscience. In fact, most readers - students of anthropology anywhere around the globe or Tswana students of their own history - will probably fail openly to notice that this trigger is present in the text. In fact, I too, when I first read it, do not remember noticing it. But it is there and it is, I propose, what sets the dynamic that motivates the following hundred or so pages of the essay.

Behind the only apparent simplicity of this narrative contrivance, a long and marvellous history of many centuries is hidden; a history of a mode of addressing the human world and of conceiving humanity by questioning its limits. This disposition was not inaugurated when Rivers first proposed the participant observation method in 1913 (in that famous essay in which he uses the word 'culture' for the first time in the plural - Rivers 1913: 5-28) or when Malinowski enacted it among the Kiriwina, starting as from 1914 (cf. Stocking 1992).

There was a proto-ethnographic disposition in the work of the great missionaries of the Belle Époque, of the Enlightened travellers of the eighteenth century, of the Jesuit priests of the seventeenth century, of the Renaissance merchant-sailors who took control over the Asian sea routes in the sixteenth century and left us such fascinating accounts as those of Duarte Barbosa (1967 [1516]) or Fernão Mendes Pinto (1992 [c. 1583]). And, beyond them, that he actually missed much of the events that day (Kuper 2001a: 5). 
Greeks like Herodotus who invented the word 'history' (1998) and, to the side of that, as we increasingly become aware today, Arab travel writers like Ibn Battuta, Buddhist scholars, Chinese encyclopaedists, etc., etc.

The challenge implicit in the sort of aporia that Schapera secretly explores is, in fact, the very driving force behind anthropology, I propose. If the concept of proto-anthropology makes any sense, it is only to the extent that anthropologists today sense that in the work of some people of the past there is an attempt at responding to this kind of aporia. Because (a) we are normally compelled to sense the communality of all humans and because (b) we are deeply sociocultural beings, whose engagement in our local moral universes is very compelling, therefore, (c) we experience sociocultural difference as a challenge to rationality. I am constantly reminded of the comic rejoinder that Obelix, the gross Gaul warrior in the series Asterix, makes every time he meets a Roman, a Saxon, an Egyptian, what have you, in their travels: "They are crazy these $X$ !", he exclaims. His limited comic-book intelligence is hardly sufficient to go beyond the primary response - thus highlighting what most of us normally hide out.

This, one might say, is the negative formulation of the ethnographic aporia - the puzzling question that drives our academic tradition. Now, in view of the very nature of the question, the response will have to pass necessarily by intersubjective engagement, since it is not about material causation that we ask, but about human engagement. If our ancestors were right, then, ethnography is about making sense of lived worlds, so it will be done by persons through an engagement with persons.

\section{INFORMANTS}

The link between the early sixteenth century traveller-merchants like Duarte Barbosa or the brilliant Jesuits who wrote roughly a century later about Ethiopia (e.g. Pero Pais and Jerónimo Lobo) and Japan (e.g. Luiz Frois) and the scholars that established anthropology as an academic discipline in the mid-nineteenth century (e.g. Morgan, Maine, Bachoffen) is certainly long and winding. It is robust, however, to the extent that the possibility of the latter depends on the existence of the former by way of the brilliant theorisers of the Enlightenment, people such as Locke, Rousseau, Leibniz and so many others (e.g. Leibniz 1994 [1697-1716]). As a matter of fact, works like Barbosa's or Ibn Battuta's became unavailable in the original soon after their writing. The information they contained remained alive, though, but mostly used in quotation, as a kind of tradition in collections of travels like Ramusio's, Purchas' or Hakluyt's. The full texts only came to wider attention in the nineteenth-century, precisely as part of the intellectual drive that motivated the institutionalization of the social sciences and that attributed renewed signification to these authors. 
In the early months of 1970, as he was finishing his book on rainmaking, Schapera was an old man living alone in retirement in a small hotel in London. He was an heir to that long tradition, of course. Still, since the early 1920s, when he learnt his trade from Radcliffe-Brown in Cape Town, many generations of anthropologists had followed their lead (Kuper 200 la, 200 lb). In the half century that lies between Molefi's investiture and the writing of Rainmaking, anthropology grew exponentially and spread all over the world.

His book, in a sense, is a bridge between two eras. That bridge, however, depends on the continued relevance of the original experience. What happens is a kind of re-actualization of humanness less dramatic but in all ways akin to that which Ryszard Kapuściński, for example, exercises when he maps out his own life as a modern foreign correspondent in terms of Herodotus' travels in the fifth century BC (2007 [2004]).

Schapera is reminiscing about experiences he had of communication with Tswana people forty years before, at a totally different political, social and ethnic conjuncture from the one in which he was writing. But the information he has to impart - and which he is anxious to unearth out of his notebooks before dying (as it happens, surprisingly, he would still be blessed with over twenty years of life in that same little hotel in London) - the knowledge he had, I was saying, was indelibly marked by the personal encounters that shaped it initially. That say, in October 1929, he met the Kgatla regent, Isang Pilane, and they struck a deal: "[...] I went up to him [...] on the same day and said: 'Look I'd like to study your tribe. Is it possible?' 'By all means,' he said. And two or three days later I was sitting in his house, and he was acting as an interpreter". Schapera explains: "Isang wanted his tribe put on the map" (in Kuper 200 la: 5-6).

In the preface to his book you can find the canonical vote of thanks to the informants. Most ethnographies bear it and for a good reason: no decent ethnographic information can be shaped without the collaboration of other people. To that extent, mutuality is written into the very nature of the pursuit. As Barbosa perceived all too clearly in his sixteenth century account of the customs of the western coast of India, there is no way in which you can just go there and see. You have to question and compile - otherwise it will never come to make sense. As he put it, you need to have engenho - that is, genius, drive, creativeness (cf. Pina-Cabral 2007).

This is how Schapera puts it in his preface:

"My greatest debt is of course to my original informants. I owe them not merely thanks but also an apology. They could and they would have told me much more if I had only thought of asking, and whatever gaps and other defects may be found in this account must be attributed above all to my not having taken full advantage of their knowledge. Almost all of them 
are now long dead. Had they been alive for me to question again, the book would be a far worthier tribute to their unfailing readiness to cooperate in my attempt to preserve for future generations of Tswana, and not solely for my professional colleagues, a record of beliefs and practices many of which were already obsolete or obsolescent at the time of my fieldwork" (1971:1).

You can hear all sorts of things in these words: the regrets of an old man, who feels he might have done more; the sadness of abandonment at having lost the partners to his original pursuit; the characteristically modernist sentiment that truth of origins is evanescent - the modernist horror at the notion that humanity may be wiping out its traces; the sense of duty to those who shared his original enchantment.

Now, like all mutualities, this one cannot be faceless. Ethnographers may be keen on passing to their readers the idea that the information they impart is objective and, as such, independent of individual perspectives. But such is never and can never be the case. In the European tradition of social anthropology there is a fear of personalizing the information: the ethnographer was supposed to have studied impartially a whole community, not any one person's idiosyncrasies in particular. That is the positivist root of the common and seldom actually theorised distaste for the word "informant".

These days, however, when asked about it, people who find themselves uncomfortable with the word, generally explain this discomfort in terms of a peculiarly unconvincing argument concerning the fact that the word "reifies" the people with whom one shared one's life during fieldwork. They seem to be unaware that our ethnographic ancestors of the classical period (those we still want to emulate today, that is, authors like Boas, Schapera or Firth, to name just three) were quite explicit about the fully human nature of the relations they had with their objects of study and indeed had more intimate and long lasting relations with their informants than the average $\mathrm{PhD}$ candidates today whose ill-thought-out ethical standards prevent them from using the word "informant" in order to clarify, specify and value the perspectival source of their ethnographic information.

I have been arguing against this trend for a very long time:

"The knowledge the ethnographer creates of the society he studies [...] is deeply marked by his social relations while in the field. [...] he cannot help but 'train' those people with whom he is in daily contact and these then become 'informants'. The avoidance of the term [...] is misguided, for it presumes that the ethnographer can have an unmarked experience of a social group. [...] The people with whom the ethnographer regularly shares gossip and conversation are his informants in the sense that their manipulation of 
information is inscribed in the ethnographer's knowledge, however many checks he may use" (Pina-Cabral 1992: 19-21).

Ethnography involves of necessity relating with people. We have learnt from the already long history of professional ethnography since the days of Malinowski and Boas that the engagement of key informants in the process of knowledge-construction that each ethnography represents marks the exercise decisively. A book like Joseph Casagrande's In the Company of Man (1960) - in which twenty of the greatest ethnographers report on the "informants" that most marked them in their distinguished research careers - will forever remain a brilliant reminder of how mutuality is written into all ethnographic information. ${ }^{3}$

As it happens, in the case of American anthropology, this fear of declaring individual relations was never as strong as in Europe, where anti-psychologistic prejudice dominated anthropology right up until the 1960s. In America, on the other hand, ethnographic exercises like Ruth Landes' unjustly forgotten book Ojibwa Woman (1971 [1938]) were, in fact, conceived from the start as collaborative exercises; in this case, between the ethnographer, the half-Indian shaman who collected the women's biographies (Maggie Wilson), the latter's daughter who wrote them down and Ruth Benedict, who received the letters in New York through the post and collected them for Ruth Landes. ${ }^{4}$ There was a deeply felt engagement in leaving behind a history of a type of female condition that, if not remembered, was thought to vanish forever to the detriment of us all. Somehow, this preoccupation grabbed the attention of them all and made the collaborative side of the project especially appealing. For two of them, Benedict and Landes, that was rooted in their explicitly held feminist views; for the others, Mrs. Wilson and her daughter, it was just a sense of respect of their own condition as Indian women.

This is how Sidney Mintz explains the difference in this aspect between the dispositions of North American anthropologists of the first part of the twentieth century and those of the Europeans of the same period:

"Studies of Native Americans [...] took shape [...] in 1879. But the anthropological study of African Americans would remain of minimal interest, at least to white scholars, for another half century. Still, a profound difference between the history of our discipline in Europe, on the one hand, and in the Western Hemisphere on the other, inheres in the simple fact that

3 And, once again, we find that ethnography echoes the most basic aspects of human experience in its mobilization of the primary modes of relating towards the purpose of gathering scientific evidence - Sahlins has recently proposed to re-define "kinship" as a "mutuality of being" (2011).

4 Recently, Sally Cole has published the actual originals of the letters (2009). 
our subjects of study, our 'primitive' peoples, were our neighbours - our illtreated, indeed often persecuted, neighbours. In this instance as in others, the anthropology we do and have done is conditioned by the history and social complexion of the society whence we come" (1996: 290).

In Europe, during the same period, academic anthropology gained its recognition as a legitimate academic field due to the perceived need to study colonised peoples (cf. Rivers' 1913 text for the Carnegie Foundation precisely addressed "anthropological research outside America"). The ever widening separation between Völkerkunde (anthropology) and Volkskunde (folklore/ethnology) - that was officially enshrined in England with the expulsion of the latter from the Royal Anthropological Institute in the 1930s - is only now breaking down as a result of the growing cosmopolitanism of the younger generations of German-speaking, Portuguese-speaking and Spanish-speaking anthropologists.

In America, at the beginning of the twentieth century, to the contrary, anthropology was part of a more general effort at constructing a national narrative. This explains also why, in North America, archaeology and linguistics (mainly of Amerindian societies) were seen as part of anthropology; whilst in Europe they were rather part of History and Letras (Humanities). This meant that the dispositions towards fieldwork diverged considerably. This is particularly visible when, for example, we compare the research experiences of Julian Stewart and E.E. Evans-Pritchard, who were full contemporaries (1902 to 1972/3; cf. Kerns 2003).

Sergei Kan has edited a series of essays discussing the long history of the way in which North American anthropologists studying Indians have been inordinately keen on being adopted into their hosts' kinship networks (2001). This has been a permanent feature since the days of Henry Morgan's own adoption by the Seneca (Iroquois) in the 1860s (Tookes 2001). In Europe, there was never such a preoccupation with formal adoption. In fact, in the days of Junod or Schapera, this would hardly have made much sense due to the colonial context.

\section{JUNOD'S DESCENT}

As my own teacher David Hammond-Tooke has documented in Imperfect Interpreters (1997), southern African ethnography grew in all of its brilliance during the first half of the century as a result of the original impetus left by RadcliffeBrown during his short stay in Cape Town. Two people in particular were essential in keeping up the flag, Isaac Schapera in Cape Town and Winifred Hoernlé in Johannesburg.

But, as we know, Radcliffe-Brown never actually carried out research in Africa - after all, he hardly had the time to do it. So, when he received from 
General Smuts, via Haddon in Cambridge, the task of founding a school of social anthropology in South Africa, he relied on the best ethnography that he could find of a southern African people in order to develop his teaching. That is how it happens that the brilliant interpretative essays in Structure and Function in Primitive Society (1952) that generation after generation of anthropologists were forced to read by their teachers, were decidedly influenced by Henri-Alexandre Junod's The Life of a South African Tribe (1962 [1926/27]). This is why Hammond-Tooke chose a photograph of Junod for the frontispiece of his history of anthropology in southern Africa.

Now, in 1895, when Junod discovered that humans were more interesting than butterflies, he turned for guidance to Sir James Frazer's famous questionnaire. Frazer's idea in writing this had been to direct people like Junod - travellers, missionaries and early colonial administrators - to gather information in a more systematic fashion. Later, Junod was also deeply influenced by the comparative perspectives of his good friend Arnold Van Gennep. His mature writings bear the mark of these two sources, which surely must be considered principal gateways to professional ethnography (cf. Harries 1981, 2001, 2007).

The following generation of southern African ethnographers - people like Schapera or Godfrey Wilson - were already professionals following on the guidelines first laid down by W.H.R. Rivers in the 1913 essay on "anthropological research outside America", written for the Carnegie Institution of Washington that I referred above (cf. Stocking 1992). The thing to remember is that, half a century later, when Turner writes his essay on his best informant (Muchona) for Casagrande's book, he is four generations away from Rivers but still directly in the same line of descent: he is a student of Max Gluckman, himself a student of Schapera and Hoernlé (Kuper 2001a: 7).

This is what Gluckman had to say concerning Van Gennep and Junod fifty years after the latter's book was published (cf. Harries 2007: 1):

"in those years, around 1930, we had few monographs by modern anthropologists to study, and I saw in looking at the reports of ethnographers, written before and after the publication of Les Rites de Passage, how Van Gennep's analysis had helped to improve descriptions. The advance was very marked to South African students, since we worked again and again through H.A. Junod's still classic study of the Thonga (Tsonga) of Mozambique. [...] Van Gennep helped raise Junod's work from run-of-themill reporting of customs, till it ranked, and still ranks, among the great monographs. Nevertheless, I would still advise a student, wishing to study rites de passage, to go to the persisting excitement of Junod rather than to Van Gennep himself" (Gluckman 1963: 7-9). 
My aim in quoting him here is to stress that, in Junod's book, later anthropologists were finding much more than just theoretically relevant information. They were also learning ways of narrating, modes of enquiry, dispositions concerning perspectival shifts, how to behave before people whose expectations one might not be able to predict, how to gather together what one sees and hears, how to identify abstract notions as they emerged in the midst of people's everyday conversation: all the things that go into the ethnographic gesture (cf. Pina-Cabral 2007). That embodied side of the ethnographic practice, and the way in which it follows along lines of succession, remains curiously underreported.

All of this became very clear to me when I read Zidji, Junod's novel concerning the troubled life of a modernising Thonga youth in turn-of-the-century South Africa (1911). Curiously, in the preface, as justification for adopting the fictional mode, Junod elides ethnographic writing - namely that he wrote the novel at the same time as he was preparing the second and definitive version of his monumental ethnographic portrait of the Thonga. He claims that missionary writings are necessarily one sided but that he wanted to introduce the public to "the whole truth concerning the three forces that shape the native soul": Paganism, Mission and Civilization. For this, he needed a different format: "Whilst it may seem paradoxical, for that portrait to be true, fiction had to intervene necessarily" (1911: v-vi). He found it reasonably easy to describe the past. In order to describe the present, however, he was bound to adopt the fictional mode. The closer the event is to the narrator the more he is bound to distance himself from sheer facticity (interpreted, of course, in his own positivistic terms). In view of early twentieth-century anthropology, there surely is an admonitory lesson to learn from this sentence.

In point of fact, the book is only marginally a novel, in as much as the author often slips into his more familiar ethnographic register, reproduces letters written by people in his mission and hardly bothers to hide the fact that his representation of the head missionary (always called by the generic term for big white missionary - Monéri) is a life-size self-portrait. For someone who knows Junod's academic writings, however, Zidji is very revealing, as it shows how his own knowledge of the local world was vicarious upon the narrated experience of others.

The usual metaphor of mirrors is here quite treacherous, since the supposed representation of the pre-colonial experience is not only mediated by the missionary-ethnographer but it originates in people who stood in the margins of both worlds - painfully mediating their contradictions. The narratives that they make to Junod are part of the way in which the informants manage their personal positions in a changing world where the stakes for misbehaving were high indeed. Therefore, even the original telling of the "facts" that precedes their presence in Junod's notebooks was itself immersed in equivocal compatibility (cf. Pina-Cabral 2010). 
For example, the whole first part of Zidji is dedicated to a detailed description of the male initiation school - the Ngoma (Junod 1911: 14-109). This is not by chance. Initiation rites are rites of passage par excellence and Junod is explicit about the fact that, without Van Gennep's theory, he would never have been able to make sense of them (1962 [1926/7], I: 72). Understanding all these practices as rites of passage meant that these were not seen as assorted customs. To the contrary, the structure that the notion of rite of passage granted them was what made it possible to see their importance to Thonga personhood in its more durable aspects.

This highlights Junod's belief that African initiation rituals format men in a durable manner: "these are physical exercises aimed at breaking the young person's pride, teaching them to obey and to endure pain. To that extent, Ngoma shapes the chief's subjects, makes them willing servants and prepares them to war" (1911: 32). Their formative influence on character is the reason why Junod saw them as one of the principal binds keeping "Natives" away "from true Christianity". ${ }^{5}$

For us, today, however, it is hard to picture quite what Junod had in mind by such a notion - that is, the prototypes by which he measures ideal performance as a Christian. We cannot afford to forget, however, that all scientific texts are marked by their historical condition - ours as much as Junod's or Schapera's - none of us rises above the conditions of our own socio-temporal insertion. Nevertheless, some of us - like Junod or Schapera - do manage to produce work that will continue to engage intellectually future generations. None of us expects to find themselves in complete agreement with Barbosa, Junod or Schapera, yet that is hardly a reason for failing to imbibe the profound lessons they have to impart.

Therefore, half a century again after Gluckman's pronunciations concerning Junod, I am prone to agree with him that the analytical explanations the Swiss missionary provides are seldom of any lasting interest to the subsequent history of anthropology and African ethnography. To the contrary, methodologically, Junod remains a major guide for ethnography. And very much the same thing can be said for Schapera - in fact, it turns out that is precisely how he saw his own legacy (in Kuper 200lb: 19). The play in cross-references and perspectival shifting, the way in which they bring together diverse information to create complex pictures, the sensitivity to the metaphorical echoes of the material presented continue to be major inspirations a century after their writing. Furthermore, his brilliant use of the notion of rites of passage as an

5 Schapera's comments concerning circumcision (in Kuper 2001a: 4, 6) and the way he sees it as approaching Tswana people from Jews are especially interesting as they echo the comments of Franz Baermann Steiner from the same period concerning Jewishness as somehow non-modern and the way it placed Jewish anthropologists in a kind of margin (Adler and Fardon in Steiner 1999, I: 40, 47-8). 
instrument of ethnographic analysis is the undertone of much of what southern African ethnography has to teach us (cf. Pina-Cabral 1997).

Unlike theory, ethnography has an uncanny capacity to overcome the analytical terms that marked its writing. This is what a century of readings of Junod can clearly demonstrate.

\section{A NEW ETHNOGRAPHIC CONJUNCTURE}

Another classical instance of how ethnographic information is dependent on a joint engagement with a local person is Turner's essay about Muchona to which I referred above (in Casagrande 1960: 333-356). There, he describes how the small man captured his attention on a dusty road in a late afternoon by presenting him with explanations for associational links that he could see Turner was missing. Much like Schapera in the 1970 preface, where there is an explicit reference to Tswana readers, in this essay we witness the emergence of a new ethnographic conjuncture.

By the 1960s, anthropologists and informants were no longer marked off by the colonial frontier in quite the same way as had been the case in the beginning of the century, when Junod wrote the final version of his monograph and Schapera started collecting the material for his own. ${ }^{6}$ By mid-century, the mutuality in ethnographic accounts had turned upon itself in a new way due to the entry into the anthropological profession of a whole lot of people whose positioning before the imperial "we/them" frontier was far more ambiguous. In short, the original perspectival shift that the ethnographic gesture involved was now reduplicated and further complexified. As it happens, this did not threaten the ethnographic tradition, it merely enriched it.

I started my own career in the late 1970s as an Africanist-trained anthropologist writing about Portugal, my country of birth. So, for me, people like Kenyatta, Fei Xiao-tung, Srinivas, and Peristiany at mid-century soon became explicit inspirations. We must not forget that there is an old tradition of national ethnography in continental Europe. Contrary to Great Britain, in continental Europe "folklore" and "ethnology" remained important forces to this day. Here, my generation was confronted with the need to combine the two traditions. We would not dispense with anthropology for its far superior intellectual achievements; still, we were literally treading on the beaten tracks of the earlier folklorists of Romantic inspiration. In Portugal, Jorge Dias and his team at the Museu de Etnologia had already started questioning the divide by the mid 1960s.

The shift was hardly limited to Europe. So I will choose an example from India to illuminate my point. To a person like T.N. Madan, writing about a

6 In fact, Schapera's case is especially interesting since Tswana chiefs like Isang Pilene were already quite modern in their valuation of Tswana history and cultural legacy (which they called "tradition"). 
small village not far from his native town of Srinagar in the late 1950s, the matter was of utmost importance. His informants belonged to the same caste as himself and saw him as one of theirs: they were all Pandits of Kashmir. Beside that, theirs is a caste of learned men of leisure. So, their relationship to Madan's project was explicitly one of active engagement as it might easily have been one of rejection, which would have totally undermined the exercise.

In fact, it became so central to the results that the ethnographer felt bound to write an appendix naming and detailing the biographies of each of his five main informants. There, after a quote from Casagrande, Madan writes:

"I regard myself as fortunate in having been able to develop particularly intimate and friendly relations with five men in the village $[\ldots]$ they gave me liberally of their time and help and generously of their affection. But for them my fieldwork would have been a less rewarding undertaking and an even less enjoyable experience. It was of these men and their help and devotion to me, that [the village head] said: 'They gave up their homes and wives and lost their night's sleep for his sake.' He also nicknamed them the 'Convoy' because they used to move about in the village together with me as often as their own work permitted” (1965: 243).

In Alto Minho, I had found myself in line with Madan's efforts to carry out the ethnography of a context where one was treated as a full participant - my own troubled attempts to deal with the issue are the core of Aromas de Urze e de Lama (2008 [1993]). It is as if Spoon/Elias had been Junod's brother, Isang Pilene, Schapera's uncle and Muchona, Turner's school companion. In fact, oddly enough, what people like Madan and myself discovered is that the difference is not half as tremendous as might have been expected. I too, like Junod before me or Laura Bohannan half way between us, felt the need to go beyond the ethnographic report into the fictional register (Bowen [Bohannan] 1964 [1954]). Not in order to show its limits, but rather, as in the two cases cited, to complete it.

In the years ahead, as audio-visual means become more central to ethnographic reporting, we will inevitably witness a trend for greater visibility to be accorded to the persons who collaborate with the ethnographer, adopting him or her into their domestic world.

\section{KNOWLEDGE AND INFORMATION}

A research method is a complex thing - it involves gathering evidence, analysing evidence, reporting on evidence. Evidence, however, is a deceptive word (cf. Gil 1998). In fact, what we gather in the field depends on what we manage to get to know as much as on what we manage to do with what we get to know - 
we are reminded here of Barbosa's use of the word engenho that suggests there is a creativity involved in the whole process. But, furthermore, since all cognition is embodied, all evidence is perspectivally inscribed.

Contrary to the more common metaphoric use of the word, strictly speaking knowledge is not something that can be shared. It is not knowledge that we impart, since knowledge is a mental event resulting from having made sense of something and retaining that in memory. What we impart is the objectified result of the knowledge we experienced: that is, information. By contrast, the latter is something that can be shared among people and can be inscribed outside people through writing or film or soundrecording in such a way as to become available again to people who had not been present at the initial encounter, for them to transform it into knowledge.

The complexity of the process is plainly impossible to ignore by ethnographers. And the reason for that is probably why the most distinguished twentieth century advocate of the ethnographic method - Edward Evans-Pritchard actually refused to "teach it". We go back to the examples of Barbosa, Junod, Schapera or Madan: the original people who imparted the knowledge are written into what is to be known, for the information they left behind was constituted as a result of knowledge obtained in face-to-face contact in historically specific conditions.

The essence of ethnography is not how many rivets were driven into the plank of a canoe but the reason why those rivets were driven. And that, as Barbosa points out in the sixteenth century, you can only understand if you ask. And, furthermore, it is not enough to report on the response: it is necessary to compound it, to interpret it, to conjugate the various parts with engenho; that ineffable engenho etnográfico of which Barbosa, Junod, Schapera, Gluckman, Turner as well as the contemporary authors whose ethnographies are discussed in this dossier were all so abundantly possessed.

\section{CONCLUSION: ETHNOGRAPHY AS TRADITION}

Ethnography, then, is a tradition; not only in the sense that its practice has a history of which we are all heirs, even when we are not all too conscious of it. Rather, over and above that, it is a tradition because it involves the whole person. Going out there and talking to people in a face-to-face context involves one as a human being in a holistic fashion. Intersubjectivity is something that can only happen to humans in their fullness.

Thus, even though Evans-Pritchard openly doubted whether ethnography could be taught, there were generations of people that followed his methodological lead. Not only in what kind of steps to take in preparation; not only in what kind of evidence to gather; not only in the dynamics launched by the force of that evidence; not only in the way of writing it down; not only 
in the tricks to use to interest the reader but also in even more imponderable ways: how to behave, how to dress, how to greet, how to listen, how to engage, how to respect, how to wait... Nigel Barley's famous strategy of "switching on the anthropological wavelength" comes to mind (1986).

Those of us who were trained as anthropologists surely remember the typically ironic method that Evans-Pritchard used to explain what he had in mind: the list of absurd responses that his teachers at the LSE supposedly provided before his leaving for Sudan in 1926 (1976: 240). The most surprising was perhaps Malinowski's injunction "not to be a bloody fool" - which was both a comment on Evans-Pritchard's undoubtedly complex personality and on what one cannot be in order to be a good ethnographer. In fact, Evans-Pritchard was perhaps the first major British anthropologist whose doctoral thesis was based on actual field research, thus signalling a major change in the modes of practicing ethnography that took place at the end of the 1920s (Kuper 2001a: 5). We also, over the past twenty years, have witnessed significant changes in our condition as ethnographers. It is imperative that we too find ways of renewing the ever-fascinating richness of the ethnographic gesture.

\section{REFERENCES}

BARbOSA, Duarte, 1967 [1516], The Book of Duarte Barbosa: An Account of the Countries Bordering on the Indian Ocean and Their Inhabitants. Ed. Mansel Longworth Dames. Liechtenstein, Nendeln, Kraus Reprint.

BARLEY, Nigel, 1986, The Innocent Anthropologist: Notes from a Mud Hut. Harmondsworth, Penguin.

BOWEN, Elenore Smith, 1964 [1954], Return to Laughter: An Anthropological Novel. New York, Anchor Books.

CASAGRANDE, Joseph, 1960, In the Company of Man: Twenty Portraits of Anthropological Informants. New York, Harper Torchbooks.

COLE, Sally, 2009, Rainy River Lives: Stories Told by Maggie Wilson. Lincoln, Nebraska University Press.

EVANS-PRITCHARD, E.E., 1976, Witchcraft, Oracles, and Magic among the Azande. Oxford, Clarendon Press, Introd. Eva Gillies.

GIL, Fernando, 1998, Modos de Evidência. Lisboa, Imprensa Nacional.

GLUCKMAN, Max (ed.), 1963, Essays on the Ritual of Social Relations. Manchester, Manchester University Press.

HAMMOND-TOOKE, W.D., 1997, Imperfect Interpreters: South Africa's Anthropologists, 19201990. Johannesburg, University of Witwatersrand Press. 
HARRIES, Patrick, 1981, "The anthropologist as historian and liberal: H.-A. Junod and the Thonga", Journal of Southern African Studies, 8 (1): 37-50.

— 2001, "Missionaries, Marxists and magic: power and the politics of literacy in SouthEast Africa”, Journal of Southern African Studies, 27 (3): 405-427.

—, 2007, Butterflies and Barbarians: Swiss Missionaries and Systems of Knowledge in South-East Africa. Johannesburg, Witwatersrand University Press.

HERODOTUS, 1998, The Histories. Oxford, Oxford University Press.

JUNOD, Henri-Alexandre, 1911 , Zidji: Etude de moeurs sud-africaines. Saint-Blaise, Foyer Solidariste.

—, 1962 [1926/7], The Life of a South African Tribe. London, Macmillan.

KAN, Sergei (ed.), 2001, Strangers to Relatives: The Adoption and Naming of Anthropologists in Native North America. Lincoln, Nebraska University Press.

KAPUŚCIŃSKI, Ryszard, 2007 [2004], Travels with Herodotus. New York, Vintage International.

KERNS, Virginia, 2003, Scenes from the High Desert: Julian Stewart's Life and Theory. Urbana, University of Illinois Press.

KUPER, Adam, 2001 a, "Isaac Schapera: a conversation. Part 1. South African beginnings", Anthropology Today, 17 (6): 3-7.

—, 2001b, "Isaac Schapera: a conversation. Part 2. London years", Anthropology Today, 18 (1): 14-19.

LANDES, Ruth, 1971 [1938], Ojibwa Woman. New York, Columbia University Press.

LEIBNIZ, Gottfried Wilhelm, 1994 [1697-1716], Writings on China. Chicago, Open Court, trans. and ed. Daniel Cook and H. Rosemont Jr.

MADAN, T.N., 1965, Family and Kinship: A Study of the Pandits of Rural Kashmir. Bombay, Asia Publishing House.

MINTZ, Sidney, 1996, "Enduring substances, trying theories", JRAI, n. s., 2: 289-290.

PINA-CABRAL, João de, 1992, "Against translation”, in J. de Pina-Cabral e John Campbell (eds.), Europe Observed. London, St. Antony/Macmillan, 1-23.

—, 1997, "The threshold diffused: margins, hegemonies and contradictions in contemporary anthropology”, in Patrick McAllister (ed.), Culture and the Commonplace: Anthropological Essays in Honour of David Hammond-Tooke. Johannesburg, Witwatersrand University Press, 31-52.

— 2007 , "Aromas de urze e de lama: reflexões sobre o gesto etnográfico", Etnográfica, XI (1): 191-212.

— 2008 [1993], Aromas de Urze e de Lama. Lisboa, Imprensa de Ciências Sociais.

—, 2010, "The dynamism of plurals: an essay on equivocal compatibility", Social Anthropology, 18 (2): 1-15.

PINTO, Fernão Mendes, 1992 [c. 1583], The Peregrination of Fernão Mendes Pinto: Soldier of Fortune, Trader, Pirate, Agent, Ambassador, during Twenty-one Years in Ethiopia, Persia, Malaya, India, Burma, Siam, Cochin-China, East Indies, China, Japan. Sailing Unchartered Uriental Seas, He Was Five Times Shipwrecked, Thirteen Times Captured, Sixteen Times Enslaved. He Met a Saint, Repented His Ways, Returned Home and Wrote His Story for His Children and for Posterity. Manchester, Carcanet in association with the Calouste Gulbenkian Foundation and the Discoveries Commission, trans. Michael Lowery, introd. Luís Sousa Rebelo.

RADClifFe-Brown, A. R., 1952, Structure and Function in Primitive Society. London, Cohen \& West. 
REIS, Eduardo, 1948, Duarte Barbosa: Pioneiro Revelador dos Costumes das Índias. Macau, Imprensa Nacional.

RIVERS, W.H.R., 1913, "Report on anthropological research outside America", in W.H. R. Rivers, A.E. Jenks and S. G. Morley, Reports upon the Present Condition and Future Needs of the Science of Anthropology. Washington, DC, The Carnegie Institute of Washington, 5-28.

SAHLINS, Marshall, 2011 , "What kinship is (part one)", JRAI, n. s., 17 (1): 2-19.

SCHAPERA, I., 1971, Rainmaking Rites of Tswana Tribes. Leiden, Afrika-Studiecentrum.

STEINER, Franz Baermann, 1999, Taboo, Truth and Religion: Selected Writings, vol. I. New York and Oxford, Berghahn Books, ed. by J. Adler and R. Fardon.

STOCKING, George W., 1992, The Ethnographer's Magic and Other Essays in the History of Anthropology. Madison, University of Wisconsin Press.

TOOKES, Elizabeth, 2001, "Lewis H. Morgan and the Senecas", in Sergei Kan (ed.), Strangers to Relatives: The Adoption and Naming of Anthropologists in Native North America. Lincoln, Nebraska University Press, 29-56. 